\title{
Experimental strabismus surgery using triamcinolone: outcomes and effects on inflammatory response
}

\author{
Utilizaçãoda triancinolona comoagente modulador da resposta inflamatória \\ na cirurgia de estrabismo em coelhos
}

\author{
Luis Eduardo Morato Rebouças de Carvalho ${ }^{1}$ \\ Milton Ruiz Alves ${ }^{2}$ \\ Maria Antonieta Longo Galvão da Silva ${ }^{3}$ \\ Marcelo Francisco Gaal Vadas ${ }^{4}$
}

\begin{tabular}{l} 
ABSTRACT \\
\hline Purpose: To evaluate the efficiency of triamcinolone(TRI) in limiting the \\
postoperative inflammatory response and scarring after strabismus \\
surgery. Methods: A prospective, two-stage, masked, controlled trial \\
was conducted. In the first stage, the inflammatory response at the \\
extraocular muscle reattachment site was analyzed after superior rectus \\
recession in ten rabbits. In the second stage, TRI (40 mg/ml) was applied \\
during surgery to the eyes of 16 rabbits with superior rectus recession. \\
As a control, contralateral eyes were treated with physiological saline. \\
Fifteen days later, exenteration was performed, and the sites of muscle \\
reattachment were processed for histological examinations. The sums of \\
the areas of the granulomas in the extraocular muscle reattachment sites \\
of controland treated eyes were compared. Result: There was a preliminary \\
inhibition effect of TRI on the inflammatory response of treated eyes \\
compared with that of control eyes. Conclusions: In the conditions of \\
conducting this study the introperative use of TRI was effective in \\
controlling the postoperative inflammatory response in rabbit eyes after \\
extraocular muscle surgery.
\end{tabular}

Keywords: Strabismus/surgery; Cicatrix; Adhesions; Triamcinolone; Rabbits

gia da Faculdade de Medicina da Universidade de São Paulo - USP - São Paulo (SP) - Brasil e na Irmandade da Santa Casa de Misericórdia de São Paulo - São Paulo (SP) - Brasil.

${ }^{1}$ Pós-Graduando da Faculdade de Medicina da Universidade de São Paulo - USP - São Paulo (SP) - Brasil; Médico Assistente do Departamento de Oftalmologia da Santa Casa de Misericórdia de São Paulo - São Paulo (SP) - Brasil.

${ }^{2}$ Livre Docente da USP - São Paulo (SP) - Brasil.

${ }^{3}$ Doutora em Medicina e Médica do Departamento de Ciências Patológicas da Santa Casa de Misericórdia de São Paulo - São Paulo (SP) - Brasil.

${ }^{4}$ Doutor em Oftalmologia pela Faculdade de Medicina da USP - São Paulo (SP) - Brasil; Médico Assistente do Departamento de Oftalmologia da Santa Casa de Misericórdia de São Paulo - São Paulo (SP) - Brasil.

Endereço para correspondência: Rua Martinico Prado, 26/181 - São Paulo (SP) CEP 01224-010

E-mail: adocarvalho@uol.com.br

Recebido para publicação em 09.08.2006

Última versão recebida em 27.09.2006

Aprovação em 04.10.2006

Nota Editorial: Depois de concluída a análise do artigo sob sigilo editorial e com a anuência do Dr. Eric Pinheiro de Andrade sobre a divulgação de seu nome como revisor, agradecemos sua participação neste processo.

\footnotetext{
$\frac{\text { INTRODUCTION }}{\text { Strabismus surgery has evolved through several stages, since impro- }}$ ved accuracy is a permanent goal $^{(1)}$. Many aspects of the underlying surgical mechanisms are, however, not entirely understood. Likewise, when it comes to abnormal muscle reattachments following surgery (adherence syndrome), many features have yet to be explained ${ }^{(2)}$.

Management of the adherence syndrome is not easy and its surgery, aimed at its improvement, frequently creates new drawbacks. Brown hypothesized, in a personal communication to Edward A. Dunlap, that once present, the adherence syndrome cannot be completely eliminated nor can its recurrence be completely avoided ${ }^{(3)}$.

Abnormal adherence can be present in different sites:

1) Between the extraocular muscle belly or its tendon (EOM) and the globe;

2) Between EOM (or its surrounding Tenon's capsule) and the overlying conjunctiva;

3) Between the sclera and the conjunctiva.

A number of different materials have been employed during surgery to prevent surfaces from adhering. Silicone sheets ${ }^{(4)}$, Seprafilm ${ }^{\circledR(5-6)}$ or gelati-
} 
nous matrices as Adcon- $\mathrm{L}^{\circledR(7)}$ have been used in the last years, with variable results. The search for other treatment resources continues.

Antimetabolic drugs, such as mitomycin $\mathrm{C}$, have been used to reduce inflammation and limit postoperative scarring ${ }^{(8-12)}$. However, results have been inconsistent and the pursuit of other management option continues.

Motivated by studies published by Tano et al. ${ }^{(13-14)}$, Dominguez wrote in $1994^{(15)}$ about new devices and drugs for intraocular use in the treatment of eye disorders, describing the use of $1 \mathrm{mg}$ triamcinolone (Bristol-Myers Squibb) administered at the conclusion of vitrectomy. Later, Dominguez proved that an in situ injection of $2 \mathrm{mg}$ triamcinolone (not considering relative penetration or extended release) produces a twenty-fold intraocular tissue concentration and a five hundred-fold lower systemic concentration as compared to a $1,000 \mathrm{mg}$ oral dose.

Despite possible intraocular pressure (IOP) increase in sensitive eyes, periocular triamcinolone may be of value to the clinician and patient. Importantly, the drug is known to inhibit neovascularization by inhibiting fibroblastic proliferation in the eye ${ }^{(16)}$ and neovascular and fibroproliferative responses in a rabbit model with vitreoproliferative retinopathy ${ }^{(13-14,17)}$. Recent studies confirm earlier findings suggesting the use of triamcinolone acetonide in the treatment of disorders such as choroidal neovascular membranes in humans ${ }^{(18-19)}$.

The purpose of the present study was to evaluate the influence of triamcinolone acetate on the inflammatory and cicatricial response following strabismus surgery in rabbits, by means of quantitative and semiquantitative histological analysis, performed subsequently to the recession of the superior rectus muscle (SR).

\section{METHODS}

\section{Experimental design}

The present study was analytical, experimental, prospective, randomized and blinded, and employed the animal model described by Minguini et al. ${ }^{(12)}$. The protocol was divided into 2 steps: In step 1, the inflammatory response at the site of muscle insertion was assessed, following the use of perimuscular triamcinolone. In step 2 the same procedures were carried out, except for cauterization of underlying sclera (intensified surgical aggression), and the inhibiting effect of triamcinolone acetate upon fibrosis and inflammatory response was verified.

\section{Animals}

Twenty-six albino New Zealand rabbits were included in the study. The animals were anesthetized with an intramuscular injection containing a mixture of ketamine hydrochloride (Ketalar ${ }^{\circledR}$, Parke Davis, $20 \mathrm{mg} / \mathrm{ml}$ ) at $25 \mathrm{mg} / \mathrm{kg}$ and an aqueous solution of 2\% 2-(2,6-xylidine)-5,6 dihydro-4H-1,3-thiazine (Rompum $^{\circledR}$, Bayer, $7 \mathrm{mg} / \mathrm{ml}$ ) at $5 \mathrm{mg} / \mathrm{kg}$. The eyes were anesthetized topically with two drops of proxymetacaine hydrochloride (Anestalcon ${ }^{\circledR}$, Alcon, $0.5 \%$ ).

\section{Ethical aspects}

All procedures to which the animals were submitted were previously approved at a research protocol review meeting with both the Ethics Committee for Laboratory Animal Science of the "Santa Casa de São Paulo" School of Medicine (FCMSC-SP) and the Ethics Committee for Research and Project Analysis (CAPPesq) of the "Hospital das Clínicas" of University of São Paulo - School of Medicine. The study followed the ethical guidelines of the Brazilian Association for Laboratory Animal Science (COBEA) and the Association for Research in Vision and Ophthalmology (ARVO) $)^{(20)}$.

\section{Step 1: Monitoring the inflammatory response}

In 10 rabbits both SR muscles were recessed by $2 \mathrm{~mm}$, using previously described techniques ${ }^{(21)}$. In one of the eyes, $0.15 \mathrm{ml}(6 \mathrm{mg})$ triamcinolone acetonide (TRI) (40 mg/ml- Ophthalmos $\left.{ }^{\circledR}\right)$ was applied to the reattachment site, whereas the fellow eye received same amounts of $0.9 \%$ physiological saline (SAL) applied over the same area. The animals were then assigned to two groups with five animals each: in Group 1, 15 days after surgery, the animals were sacrificed and their eyeballs were carefully exenterated without causing damage to the scleromuscular junction. The eyes were then prepared for histological analyses followed by a comparison between the two treatments. In Group 2, the animals were kept in captivity for one month after which they were submitted to the same procedure as those of group 1.

\section{Step 2: Enhancing the inflammatory response and evaluating the effect of triamcinolone}

In 16 rabbits the $\mathrm{SR}$ were recessed by $2 \mathrm{~mm}$, as described for Step 1. However, in these animals an area of the underlying scleral bed measuring $1 \mathrm{~cm}^{2}$ was cauterized. Subsequently, as described above, physiological saline was applied to one eye and triamcinolone to the other. Fifteen days later the rabbits were sacrificed and the eyes were exenterated.

\section{Histological and morphometric analyses}

The eyes included in the study were fixed in $10 \%$ buffered formaldehyde and embedded in paraffin. Three consecutive sagittal sections were made at the new point of insertion of the superior rectus muscle. The tissues were examined microscopically and macroscopically through staining with hematoxylin eosin (HE) and Masson's trichrome (MT) in order to evaluate the severity of inflammation and fibrous proliferation. The grading of the inflammation was made through semiquantitative analysis ${ }^{(22)}$ performed by a blinded pathologist.

The following grading was used:

0 : inflammatory infiltrate absent / fibrous proliferation absent.

1: mild inflammatory infiltrate (prevalence of lymphocytes) / small area of fibrosis.

2: moderate inflammatory infiltrate (prevalence of lymphocytes, plasmocytes and scattered macrophages) / moderate area of fibrosis. 
3: intense inflammatory infiltrate (presence of lymphocytes, plasmocytes, macrophages and neutrophils) / necrosis present / extensive area of fibrosis.

The slides were reviewed by the author and by physicians from the Department of Morphology at the FCMSC-SP. A Zeiss microscope was used (model Axioskop 40, coupled to a computer with an Intel Pentium III processor running the software Axiovision 3.1) in order to determine the size of the area affected with granulomatosis (tecidual inflammatory reaction around the suture material). The ocular tissue was measured using the cursor in all fields with a 50x magnification.

All slides were measured and photographed (total of 112 photographs). The number of photographs required depended on the need to measure the total area under investigation; thus, certain slides were photographed more than once.

\section{Statistical analysis}

The statistical analysis consisted of a variance analysis (ANOVA) comparing average values with a factor and with repetition of four levels and measures ${ }^{(23)}$.

Factor levels:

- physiological saline - HE

- triamcinolone - HE

- physiological saline - MT

- triamcinolone - MT

Contrasts were prepared for the following comparisons:

- physiological saline - HE x triamcinolone - HE

- physiological saline - MT x triamcinolone - MT

- physiological saline - HE x saline solution - MT

- triamcinolone - HE x triamcinolone - MT

A chi-square test was used to verify the existence of dependence between the severity of the inflammation (absent, mild, moderate or intense) and the substance (physiological saline or triamcinolone) $)^{(24)}$.

Likewise, Pearson's correlation coefficients were calculated and dispersion diagrams were constructed in order to determine the existence of a relationship between the area affected with granulomatosis and the weight of the animals ${ }^{(24)}$.

In all tests, the level of statistical significance was set at $5 \%(\mathrm{p}<0.05)$.

\section{RESULTS}

In Step 1, two groups of 5 rabbits each (20 eyes) were evaluated. Since no inflammation was observed in either group, the anti-inflammatory and cicatricial action of triamcinolone could not be verified.

In Step 2, with intensified surgical aggression, a cicatricial and anti-inflammatory response was observed in rabbits treated with triamcinolone. The results are displayed in the Figures and Tables below.

Using ANOVA with repeated measures it was determined that:

1) The average values of the four groups differed $(p<0.01)$.

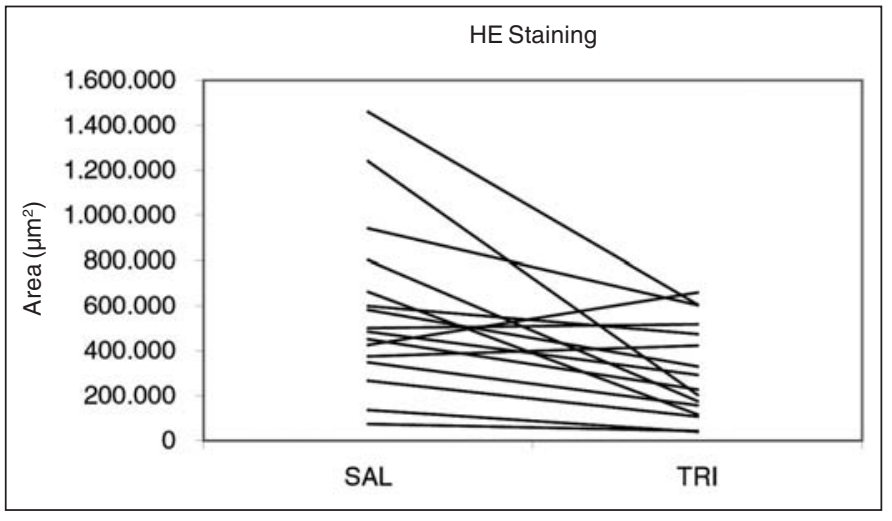

Figure 1 - Individual profiles for areas of granulomatosis according to applied substance (SAL= physiological saline or TRI= triamcinolone) in rabbits submitted to strabismus surgery (hematoxylin-eosin staining)

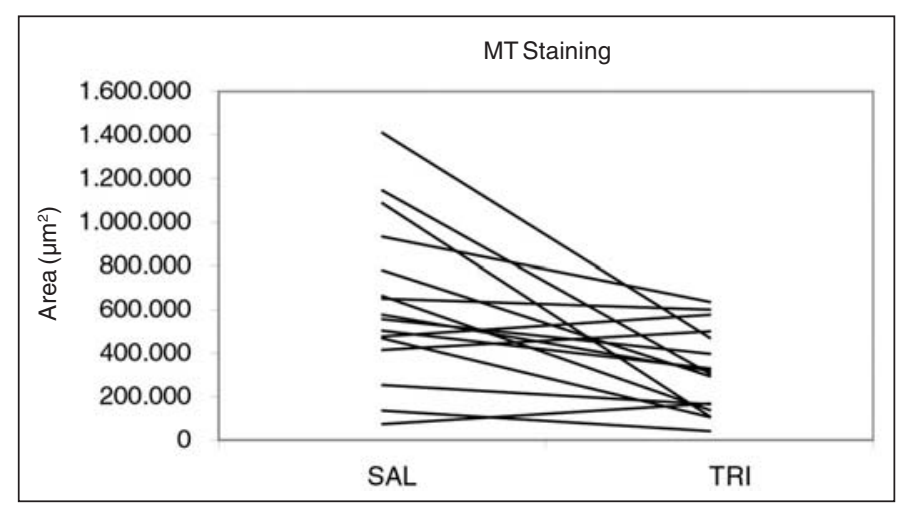

Figure 2 - Individual profiles for areas of granulomatosis according to applied substance (SAL= physiological saline or $T R I=$ triamcinolone) in rabbits submitted to strabismus surgery (Masson's trichrome staining)

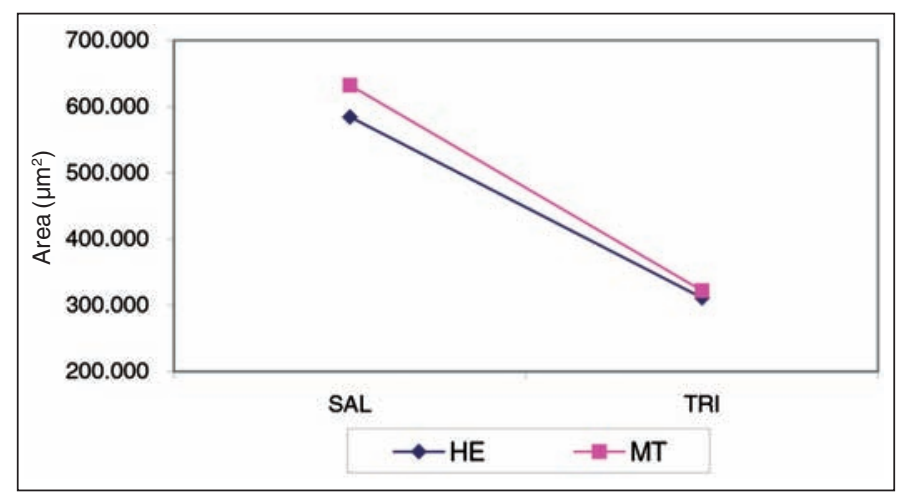

Figure 3 - Average profiles for areas of granulomatosis in rabbits submitted to strabismus surgery according to applied substance (SAL= physiological saline or TRI= triamcinolone) and staining medium (HE= hematoxylin-eosin or MT= Masson's trichrome)

Using ANOVA with the contrasts it was determined that:

1) With HE staining, the average area was greater for physiological saline than for triamcinolone $(\mathrm{p}=0.005)$.

2) With MT staining, the average area was greater for physiological saline than for triamcinolone $(\mathrm{p}=0.003)$. 


\begin{tabular}{|c|c|c|c|}
\hline Stain & & Areas of granul & natosis $\left(\mu \mathrm{m}^{2}\right)$ \\
\hline medi & & Physiological saline & Triamcinolone \\
\hline $\mathrm{HE}$ & Average & 584361 & 311242 \\
\hline & Standard deviation & 373915 & 209984 \\
\hline & Minimum & 74240 & 39240 \\
\hline & Median & 493010 & 260443 \\
\hline & Maximum & 1459552 & 659343 \\
\hline MT & Average & 632349 & 321961 \\
\hline & Standard deviation & 366180 & 192253 \\
\hline & Minimum & 72157 & 41572 \\
\hline & Median & 565837 & 311603 \\
\hline & Maximum & 1409530 & 635433 \\
\hline Total & Average & 608355 & 316602 \\
\hline & Standard deviation & 364865 & 198115 \\
\hline & Minimum & 72157 & 39240 \\
\hline & Median & 528754 & 298964 \\
\hline & Maximum & 1459552 & 659343 \\
\hline
\end{tabular}

\begin{tabular}{|c|c|c|c|c|c|c|}
\hline & \multicolumn{2}{|c|}{$\begin{array}{l}\text { Absent } \\
\text { or mild }\end{array}$} & \multicolumn{2}{|c|}{$\begin{array}{l}\text { Moderate } \\
\text { or intense }\end{array}$} & \multicolumn{2}{|c|}{ Total } \\
\hline & $\mathbf{N}$ & $(\%)$ & $\mathbf{N}$ & $(\%)$ & $\mathbf{N}$ & $(\%)$ \\
\hline Physiological saline & 2 & (12.50) & 14 & $(87.50)$ & 16 & $(100)$ \\
\hline Triamcinolone & 13 & (81.25) & 3 & (18.75) & 16 & (100) \\
\hline Total & 15 & $(46.90)$ & 17 & $(53.10)$ & 32 & $(100)$ \\
\hline
\end{tabular}

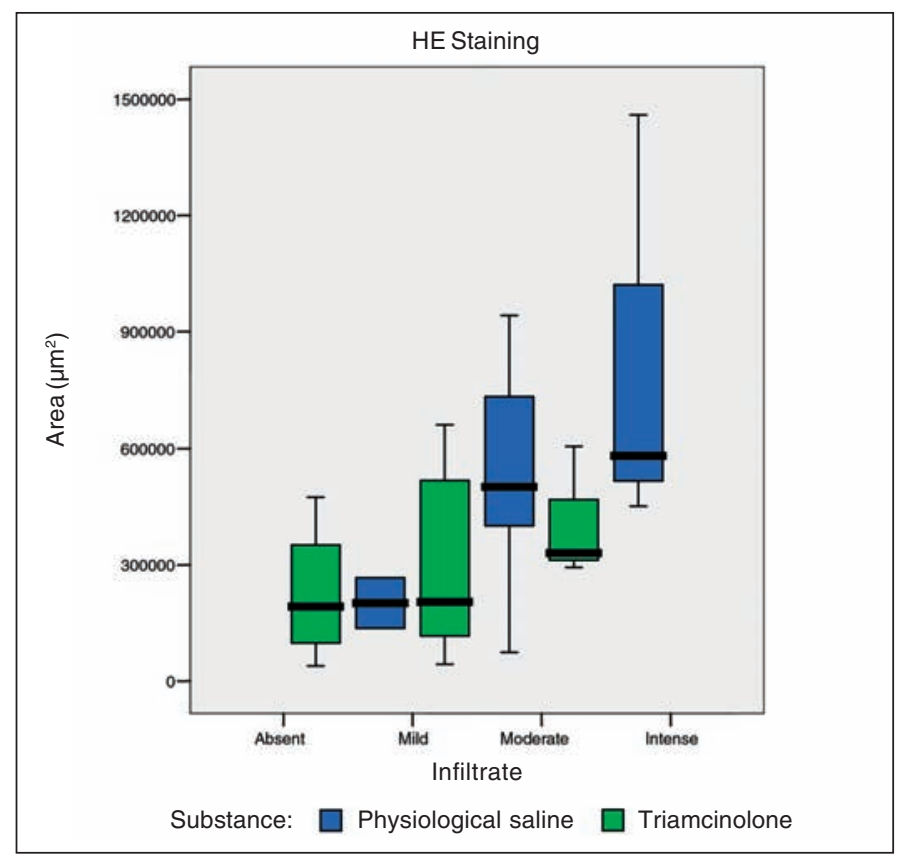

Figure 4 - Box plot of areas of granulomatosis according to severity of inflammation (hematoxylin-eosin staining)

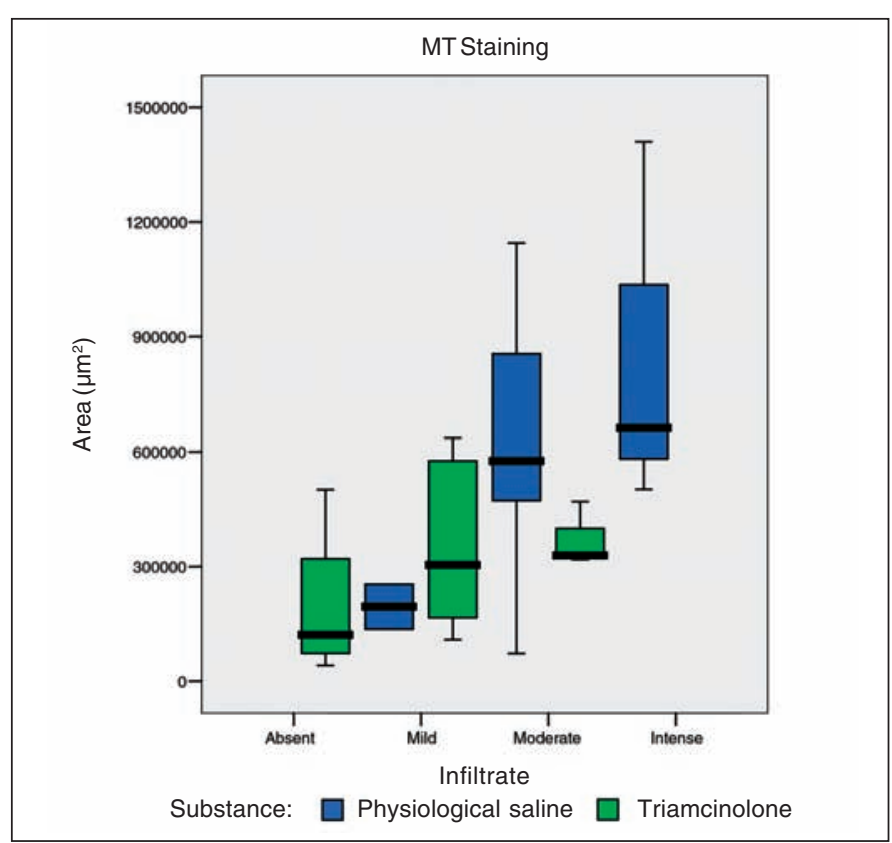

Figure 5 - Box plot of areas of granulomatosis according to severity of inflammation (Masson's trichrome staining)

\begin{tabular}{lc|}
$\begin{array}{l}\text { Table 3. Descriptive measures for the weight of the animals included } \\
\text { in the study }\end{array}$ \\
& Weight $\mathbf{( k g )}$ \\
Average & 2.5 \\
Standard deviation & 0.2 \\
Minimum & 2.0 \\
Median & 2.5 \\
Maximum & 2.9 \\
Number of animals & 16 \\
\hline
\end{tabular}

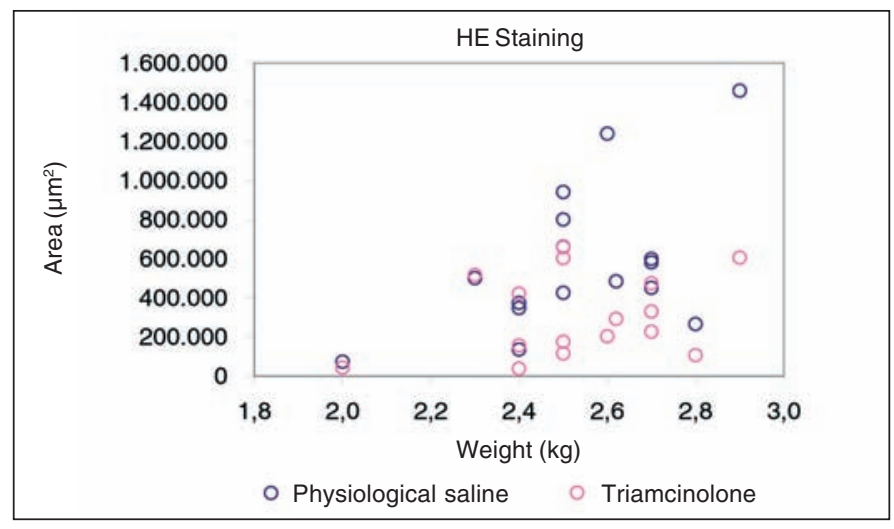

Figure 6 - Dispersion diagram of areas of granulomatosis in rabbits submitted to strabismus surgery according to weight (hematoxylineosin staining)

3) In the group treated with physiological saline, the measured area was the same, on the average, for the two staining media $(\mathrm{HE}$ and MT $)(\mathrm{p}=0.225)$.

4) In the group treated with triamcinolone, the measured 


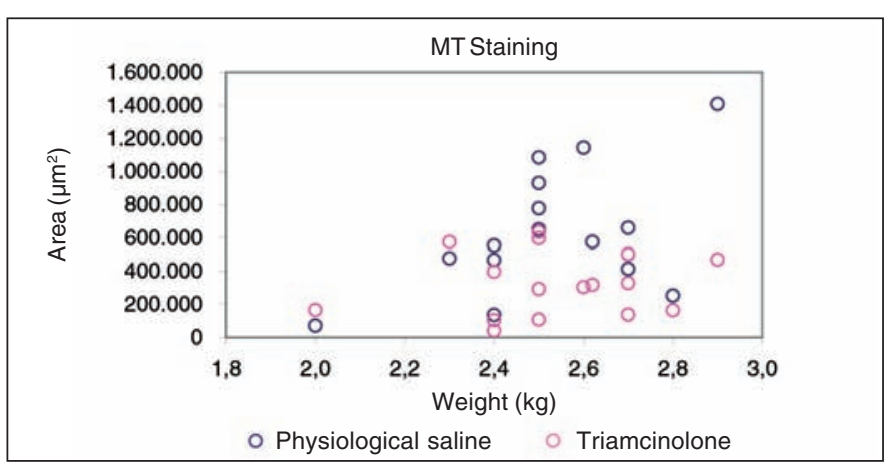

Figure 7 - Dispersion diagram of areas of granulomatosis in rabbits submitted to strabismus surgery according to weight (Masson's trichrome staining)

area was the same, on the average, for the two staining media (HE and MT) $(\mathrm{p}=0.565)$.

The findings of the chi-square test indicate that the intensity of the inflammation depends on the provided postsurgical treatment (physiological saline or triamcinolone) $(\mathrm{p}<0.001)$. The proportion of moderate to intense inflammation was greater in animals treated with physiological saline.

\section{DISCUSSION}

This study was intended to investigate the effects of triamcinolone acetate upon the inflammatory and cicatricial reaction caused by strabismus surgery in rabbits. Using the animal model described by Minguini et al. aggression was intensified by cauterizing the scleral bed underlying the new site of insertion of the SR.

Earlier studies have described the anti-inflammatory properties and neovascularization inhibition ability of triamcinolone, but very little has been published regarding strabismology ${ }^{(25)}$.

Two staining methods were performed according to which biologic or chemical feature was being assessed. The hematoxylin and eosin (HE) stain is useful to demonstrate the type of tissue reaction that is present, and is the most commonly used in medical practice. Hematoxylin is a basic dye that stains acidic structures such as nuclear chromatin, producing a blue tone. Eosin is an acidic dye, therefore stains basic substances in the cytoplasm, producing an intense pink. Masson's trichrome stain is useful to identify collagen within muscle tissue. These staining methods identify the muscular nuclei in tone of blue black color or, cytoplasm in red tone, staple fibers in red tone and the collagen in tone of blue.

The method used in the present study incorporates a novel way of collecting objective measurements of areas affected with granulomatosis. In addition to the analysis of histological characteristics of tissues at the new site of insertion of the superior rectus muscle, the used technique made it possible to perform statistical analyses, showing that the area affected with granulomatosis was significantly smaller in eyes treated with triamcinolone than in controls.

The inflammatory infiltrate observed in sections from affected areas was more intense in control eyes, with prevalence of cells typical of intense inflammatory processes (neutrophils and macrophages) (Figure 8).

Fibrosis is a common finding and an important complication of granulomatosis. Although fibrosis was not measured directly in this study, the results suggest it was proportional to the severity of the inflammatory process.

The method used in the present study incorporates a novel way of collecting objective measurements of areas affected with granulomatosis. In addition to the analysis of histological characteristics of tissues at the new site of insertion of the superior rectus muscle, the technique used made it possible to perform statistical analyses, showing that the area affected with granulomatosis was significantly smaller in eyes treated with triamcinolone than in controls (Figure 9A and B).

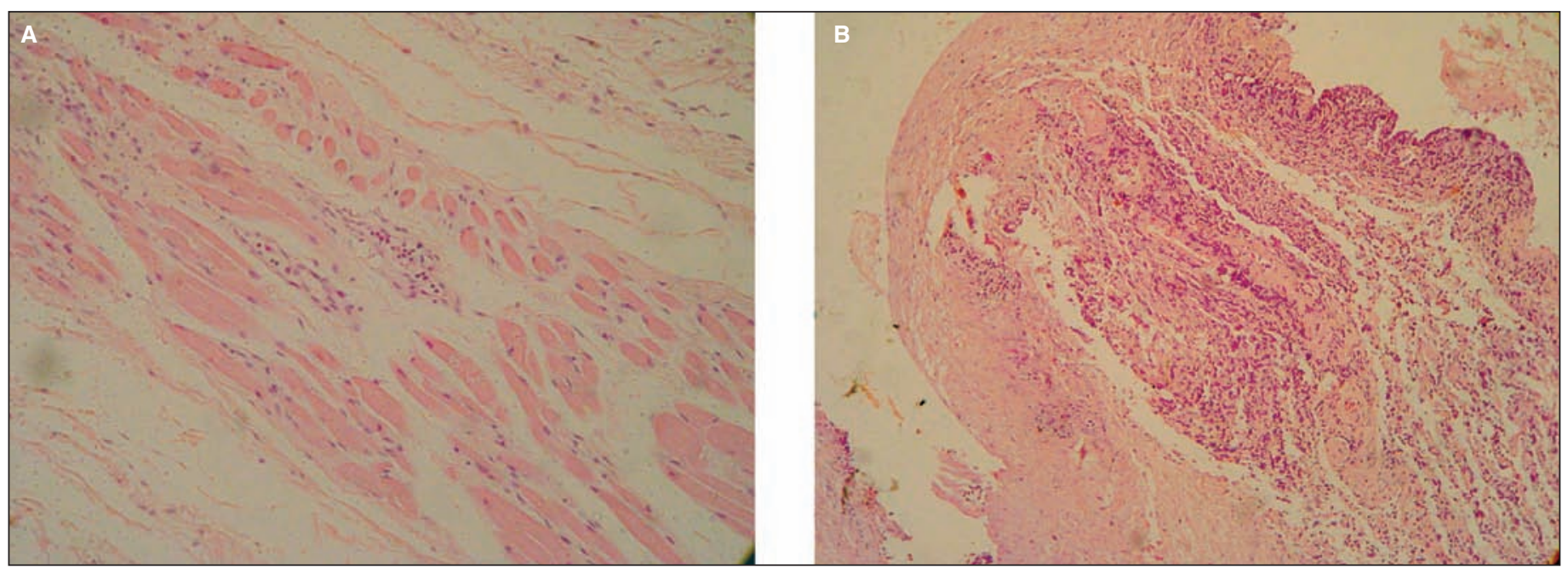

Figure 8 - Histological appearance of the SR muscle in an eye treated with TRI (A) and in a control eye (B). Compared with the treated eye, the control shows a more prominent inflammatory response. (HE, original magnification, X50) 


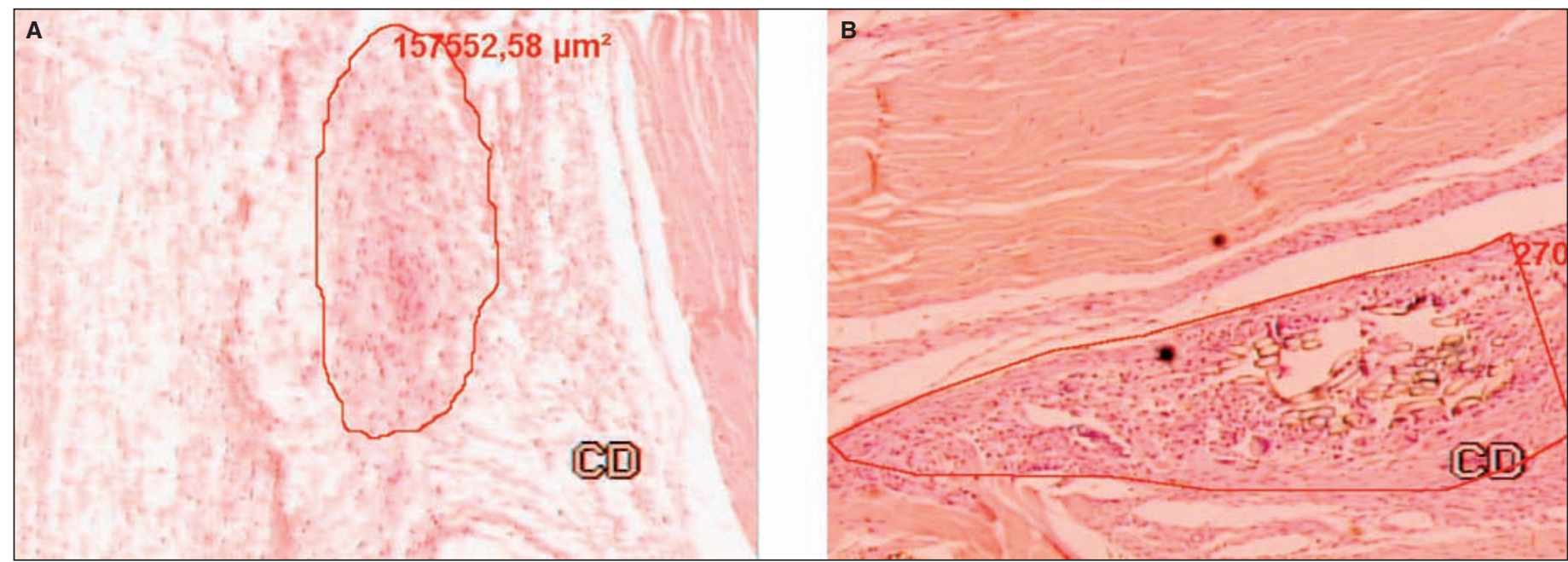

Figure 9 - Histologic appearance of the SR muscle in an eye treated with triamcinolone (A) and in a control eye (B). Compared with the control, the treated eye shows a less prominent inflammatory response, with less fibrous tissue around the suture material (marked with red line). (HE, original magnification, $\mathrm{X} 50$ )

Individual analysis showed that rabbits number 5, 11 and 13 had a paradoxically increased granulomatous response in eyes treated with TRI. However, the difference observed between these eyes and their controls was actually very small, hardly influencing the overall trend.

The purpose of crossing weight data and inflammatory response was based on the assumption that heavier rabbits may exhibit a more exuberant inflammatory reaction. Albeit data may reveal some sort of correlation, appropriate statistical analysis failed to do so (Pearson's correlation coefficient).

\section{CONCLUSION}

Under the conditions of the present study, triamcinolone at $40 \mathrm{mg} / \mathrm{ml}$ efficiently reduced inflammation in rabbits submitted to strabismus surgery, reducing the intensity of the inflammatory infiltrate in areas affected with granulomatosis.

\section{ACKNOWLEDGMENTS}

The authors thank everyone at "Santa Casa de São Paulo" School of Medicine and "Hospital das Clínicas" of University of São Paulo - School of Medicine, from the departments of Experimental Surgery, Pathology, and Morphology for their contributions.

\section{RESUMO}

Objetivo: Avaliar a eficiência da triancinolona (TRI) como agente modulador da resposta inflamatória e cicatricial em coelhos submetidos à cirurgia de estrabismo. Métodos: Foi realizado estudo prospectivo, mascarado, em dois estágios. No primeiro estágio 10 coelhos foram submetidos a retrocesso do músculo reto superior em ambos os olhos, aplicando-se triancinolona ( $40 \mathrm{mg} / \mathrm{ml})$ em um dos olhos e como controle, solução salina nos olhos contralaterais. Quinze dias e trinta dias após, os animais foram exenterados e o material do sítio de reinserção muscular foi submetido à análise qualitativa $\mathrm{e}$ quantitativa. No segundo estágio, com incrementação da agressão cirúrgica, 16 coelhos foram submetidos aos mesmos procedimentos com exenteração e análise dos tecidos após 15 dias. Resultado: Houve efeito inibitório da TRI na resposta inflamatória dos olhos tratados quando comparados aos olhos-controle. Conclusões: Nas condições de realização do presente estudo o uso per-operatório da TRI foi efetivo no controle da resposta inflamatória em olhos de coelhos submetidos à cirurgia de estrabismo.

Descritores: Estrabismo/cirurgia; Cicatriz; Aderências; Triancinolona; Coelhos

\section{REFERENCES}

1. Ingram RM. Tissue repair after the operations of recession and resection. $\mathrm{Br} \mathrm{J}$ Ophthalmol. 1965;49:18-28.

2. Knapp P. Treatment of divergent deviations. In: Allen H (Editor). Strabismus Ophthalmic Symposium II. St. Louis: CV Mosby; 1958.

3. Dunlap EA. Surgery of muscle adhesions and effects of multiple operations. Br J Ophthalmol. 1974;58(3):307-12.

4. Shokida MF. Use of a silicone sheet for delayed adjustable strabismus surgery. Ophthalmic Surg. 1993;24(7):486-8.

5. Assaf AA. Seprafilm in repeated strabismus surgery to reduce surgical scarring. In: Lennerstrand G, editor. Advances in strabismology. Buren, The Netherlands: Aeolus Press; 1999. p. 377-80.

6. Ozkan SB, Kir E, Culhaci N, Dayanir V. The effect of Seprafilm on adhesions in strabismus surgery - an experimental study. J AAPOS. 2004;8(1):46-9.

7. Choi MY, Auh SJ, Choi DG, Chang BL. Effect of ADCON-L on adjustable strabismus surgery in rabbits. Br J Ophthalmol. 2001;85(1):80-4.

8. Cruz OA, Matkovich L. Effects of intraoperative topical mitomycin-C on strabismus surgery in the rabbit: a preliminary study. Ophthalmic Surg. 1995;26(3):237-40.

9. Cruz OA. Evaluation of mitomycin to limit postoperative adhesions in strabismus surgery. J Pediatr Ophthalmol Strabismus. 1996;33(2):89-92.

10. Brooks SE, Ribeiro GB, Archer SM, Elner VM, Del Monte MA. Fat adhe- 
rence syndrome treated with intraoperative mitomycin-C: a rabbit model. J Pediatr Ophthalmol Strabismus. 1996;33(1):21-7.

11. Ohtsuki $\mathrm{H}$, Hasebe $\mathrm{S}$, Okuda $\mathrm{Y}$, Ogou T. Is mitomycin effective in preventing muscle migration after hang-back recession in a rabbit model? Ophthalmologica. 1997;211(6):373-9.

12. Minguini N, Monteiro de Carvalho KM, Akaishi PM, De Luca IM. Histologic effect of mitomycin $\mathrm{C}$ on strabismus surgery in the rabbit. Invest Ophthalmol Vis Sci. 2000;41(11):3399-401.

13. Tano Y, Chandler D, Machemer R. Treatment of intraocular proliferation with intravitreal injection of triamcinolone acetonide. Am J Ophthalmol. 1980;90 (6):810-6.

14. Tano Y, Chandler DB, McCuen BW, Machemer R. Glucocorticosteroid inhibition of intraocular proliferation after injury. Am J Ophthalmol. 1981;91(2):184-9.

15. Dominguez Collazo A. [Devices and drugs introduced intraocularly for the treatment of eye diseases "in the office"]. An R Acad Nac Med (Madr). 1994; 111(2):377-85. Spanish.

16. Nguyen KD, Lee DA. Effect of steroids and nonsteroidal antiinflammatory agents on human ocular fibroblast. Invest Ophthalmol Vis Sci. 1992;33(9):2693-701.

17. Antoszyk AN, Gottlieb JL, Machemer R, Hatchell DL. The effects of intravitreal triamcinolone acetonide on experimental pre-retinal neovascularization. Graefes Arch Clin Exp Ophthalmol. 1993;231(1):34-40.
18. Danis RP, Bingaman DP, Yang Y, Ladd B. Inhibition of preretinal and optic nerve head neovascularization in pigs by intravitreal triamcinolone acetonide. Ophthalmology. 1996;103(12):2099-104.

19. Ciulla TA, Criswell MH, Danis RP, Hill TE. Intravitreal triamcinolone acetonide inhibits choroidal neovascularization in a laser-treated rat model. Arch Ophthalmol. 2001;119(3):399-404.

20. Statement for the Use of Animals in Ophthalmic and Visual Research. In: Association for Research in Vision and Ophthalmology - ARVO 2000 [homepage on the Internet]. Rockville, MD: The Association for Research in Vision and Ophthalmology (ARVO); c2005. Available from: ttp://hwww.arvo.org/eweb/dynamic page aspx $?$ site $=$ arvo $2 \&$ webcode $=$ AnimalsResearch $\&$ printerfriendly $=$ yes

21. Parks MM. Cirurgia de estrabismo - Atlas e texto. São Paulo: Roca; 1983.

22. Von Hertwig R, Rigueiro MP, Rodrigues PD, Torres FAN, Nishi M. Efeito imunossupressor da ciclosporina intra-muscular administrada em diferentes períodos pós-operatórios em um modelo de transplante penetrante de córnea em ratos. Arq Bras Oftalmol. 1999;62(6):717-25.

23. Neter J, Kutner MH, Nachtshein CJ, Wasserman W. Applied linear statistical models. 4th ed. Chicago: Irwin; 1996.

24. Bussab WO, Morettin PA. Estatística básica. 5. ed. São Paulo: Saraiva; 2004

25. Oh SO, Lee J. Reduction of postoperative adhesions in strabismus surgery. Korean J Ophthalmol. 1992;6(2):76-82.

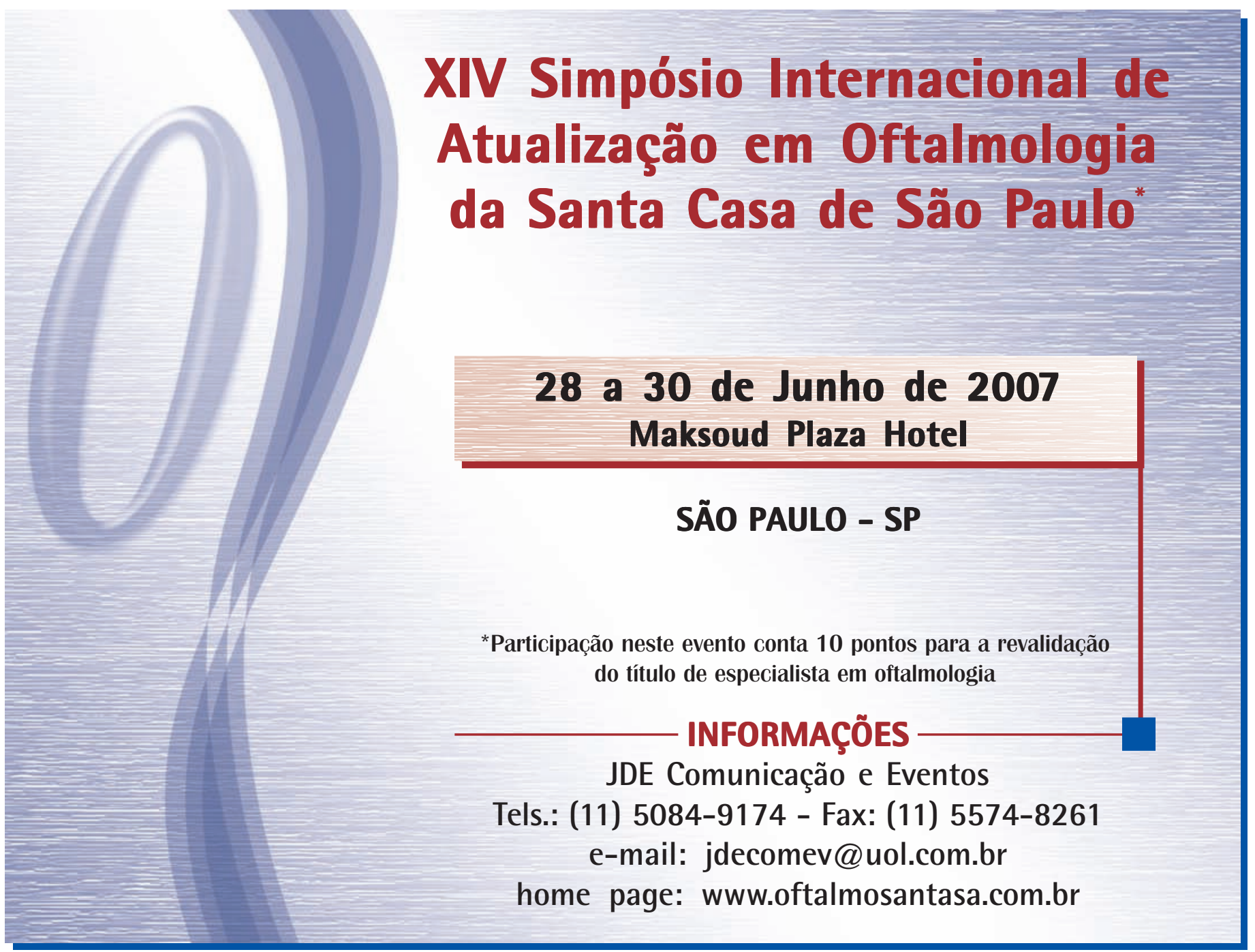

